\title{
Congenital heart malformations in Jutland, Denmark: a three year necropsy study in children aged $0-14$ years \\ Epidemiology and classification according to sequential segmental analysis
}

\author{
A VESTERBY, * K NIELSEN, $\dagger$ L BORG, * S PAULSEN, $†$ U BAANDRUP* \\ From the $\star$ University Institute of Pathology, Kommunehospitalet, Arhus; and the $†$ Institute of Pathology, \\ Ålborg Sygehus Nord, Ålborg, Denmark
}

SUMMARY The use of sequential segmental analysis for describing congenital heart malformations was the method of assessment used in a prospective necropsy study covering Jutland, a well defined geographical and demographic area of Denmark. The study group was 1154 children of whom $261(22.6 \%)$ had a congenital heart malformation. The most common malformations were ductus arteriosus and ventricular septal defect and there were 77 cases in which connections between chambers or between chambers and great arteries were anomalous (68 liveborn; 37 male and 31 female: nine stillborn; two male and seven female). No difference in sex distribution or seasonal variation was found between those with congenital heart disease and those without. Extracardiac malformations and chromosomal abnormalities were more often seen in children with congenital heart malformation than in those without $(30.3 \%$ vs $16.6 \%)$.

The sequential segmental analysis is a logical and precise way of describing congenital heart malformations and it should be routinely used to classify cases of congenital heart malformation.

Difficulties with the use of nomenclature in the routine management of paediatric cases of congenital heart disease prompted us to test a system of nomenclature based upon identification of segmental connections that was proposed by Shinebourne $e t$ al in 1976. ${ }^{1}$

We present a necropsy study of congenital heart malformations collected prospectively in a welldefined geographical and demographic area of Denmark in which necropsy is often performed.

\section{Patients and methods}

The children included in the study died between 1 January 1977 and 31 December 1979. They were $0-14$ years old or were stillbirths weighing $\geqslant 1000 \mathrm{~g}$. The cases were collected prospectively and without

Requests for reprints to Dr U Baandrup, University Institute of Pathology, Kommunehospitalet, 8000 Århus C, Denmark.

Accepted for publication 23 July 1987 selection. During the study period there were 91531 livebirths and 521 registered stillbirths. Officially the gestational age of a stillbirth is 28 weeks, but we chose to use birthweight as an inclusion criterion because it is more accurate and convenient. Jutland (fig 1), is a demographically well-defined part of Denmark with a population of 2313034 (1 January 1978). Jutland is divided into seven counties and we obtained separate results for these to investigate whether there were geographical differences.

All ten departments of morbid anatomy and two institutes of forensic medicine serving the area were informed of the study by letter and orally. Written consent was obtained from the departments. Every few months we sent them written reminders. Our tracing rate for collecting specimens and data was cross-checked against the files of the National Health Board, to which all deaths, including stillbirths, are reported. This meant that we could also trace children who were born in the area of study but who died outside it. 


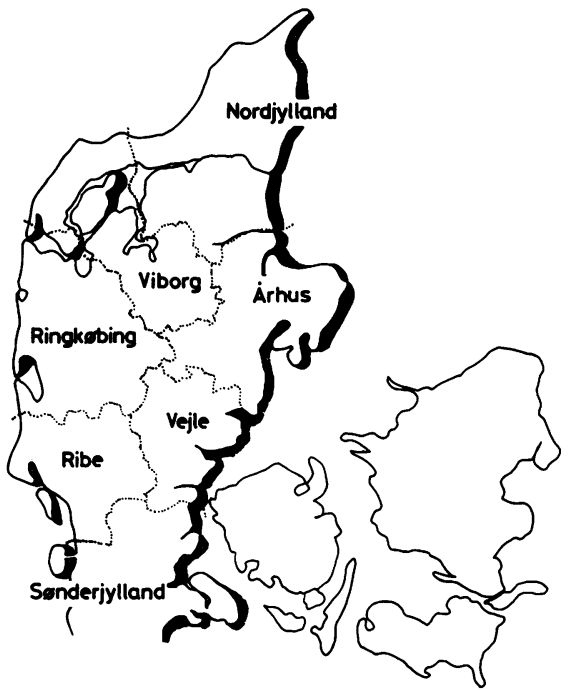

Fig 1 Jutland (7 counties).

During the study period 1357 children aged 0-14 years died and there were 521 registered stillbirths (a total of 1878 children). The statistics of the National Health Board showed that necropsy was planned in 1320 cases $(70.3 \%)$ and performed in 1293 cases $(68.8 \%)$. We studied $1154(61 \cdot 4 \%)$ cases (fig 2).

A forensic necropsy was performed in 133 cases $(11.5 \%)$, which were mainly cot deaths. The remaining 1021 necropsies were performed at the request of the hospital. We personally investigated heart-lung preparations or the entire organ block in $894(77.5 \%)$. In 260 cases $(22.5 \%)$ we went through the necropsy notes and contacted the pathologists who performed the necropsy.

The method of investigation was the sequential segmental analysis. ${ }^{12}$ Probe patency of the foramen ovale and patency of the ductus arteriosus beyond one month of age were regarded as definite heart malformations. In children $<1$ month of age or in stillbirths these findings were not categorised as heart malformations.

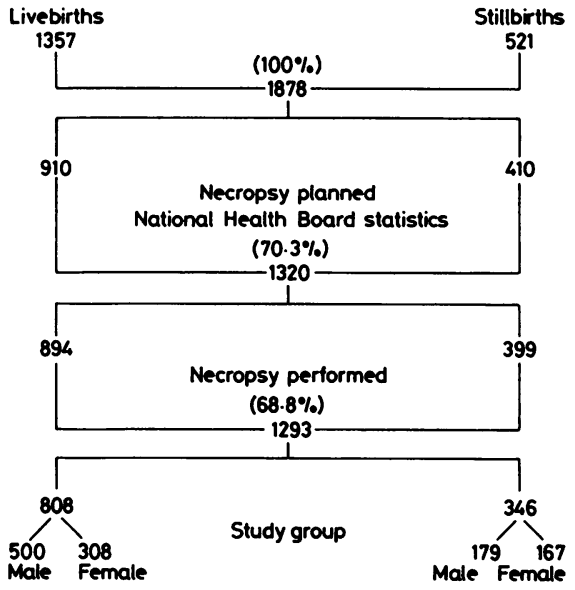

Fig 2 Selection of study population.

In each case a questionnaire was prepared for electronic data processing. The statistical tests that we used are stated in the text. Types and constellations of malformations have been listed by number only.

\section{Results}

\section{EPIDEMIOLOGY}

We studied $808(70 \%)$ livebirths and $346(30 \%)$ stillbirths. There were 500 liveborn boys $(61.9 \%)$ and 308 girls $(38.1 \%)$ and 179 stillborn boys $(51.7 \%)$ and 167 girls (48.3\%) (fig 2).

The frequency of necropsy varied considerably in the seven counties (table 1). According to the National Health Board the mean frequency of necropsy was $68 \cdot 8 \%$. Our 1154 necropsies represent $90.3 \%$ of livebirths and $86.7 \%$ of stillbirths (tracing rate). Two hundred and sixty one children $(22.6 \%)$ had a congenital heart malformation (fig $3 a$ and $b$ ) (40 stillbirths $(15 \cdot 3 \%)$ and 221 livebirths $(84 \cdot 7 \%)$ ). The frequency of congenital heart malformation was $21.6 \%$ in boys and $24 \%$ in girls $\left(\chi^{2}\right.$ test $=0.88$, p > 0.3). Congenital heart malformation was more

Table 1 Frequency of necropsy and our tracing rate in seven counties

\begin{tabular}{|c|c|c|c|c|}
\hline \multirow[b]{2}{*}{ County } & \multicolumn{2}{|l|}{ Stillbirths } & \multicolumn{2}{|l|}{ Livebirths } \\
\hline & $\begin{array}{l}\text { Necropsies/deaths } \\
\text { (frequency \%) }\end{array}$ & Tracing rate $(\%)$ & $\begin{array}{l}\text { Necropsies/deaths } \\
\text { (frequency \%) }\end{array}$ & Tracing rate $(\%)$ \\
\hline $\begin{array}{l}\text { Nordjylland } \\
\text { Århus } \\
\text { Viborg } \\
\text { Ringkøbing } \\
\text { Ribe } \\
\text { Sønderiylland } \\
\text { Vejle } \\
\text { Mean }\end{array}$ & $\begin{array}{cc}87 / 96 & (90 \cdot 6) \\
122 / 145(84 \cdot 1) \\
25 / 58(43 \cdot 1) \\
25 / 50(50 \cdot 0) \\
52 / 53(98 \cdot 1) \\
50 / 63(79 \cdot 4) \\
38 / 56(67 \cdot 9) \\
399 / 521(76 \cdot 6)\end{array}$ & $\begin{array}{l}87 / 87(100) \\
91 / 122(74 \cdot 6) \\
22 / 25 \quad(88 \cdot 0) \\
24 / 25 \quad(96 \cdot 0) \\
52 / 52(100) \\
32 / 50(64 \cdot 0) \\
38 / 38(100) \\
346 / 399(86 \cdot 7)\end{array}$ & $\begin{array}{rr}218 / 270 & (81 \cdot 0) \\
209 / 323 & (64 \cdot 7) \\
73 / 121 & (60 \cdot 3) \\
96 / 164 & (58 \cdot 5) \\
83 / 130 & (63 \cdot 8) \\
96 / 157 & (61 \cdot 1) \\
119 / 192 & (62 \cdot 0) \\
894 / 1357 & (65 \cdot 9)\end{array}$ & $\begin{array}{c}205 / 218(94 \cdot 0) \\
195 / 209(93 \cdot 3) \\
64 / 73(87 \cdot 7) \\
90 / 96(93 \cdot 8) \\
69 / 83(83 \cdot 1) \\
77 / 96(80 \cdot 2) \\
108 / 119(90 \cdot 8) \\
808 / 894(90 \cdot 3)\end{array}$ \\
\hline
\end{tabular}




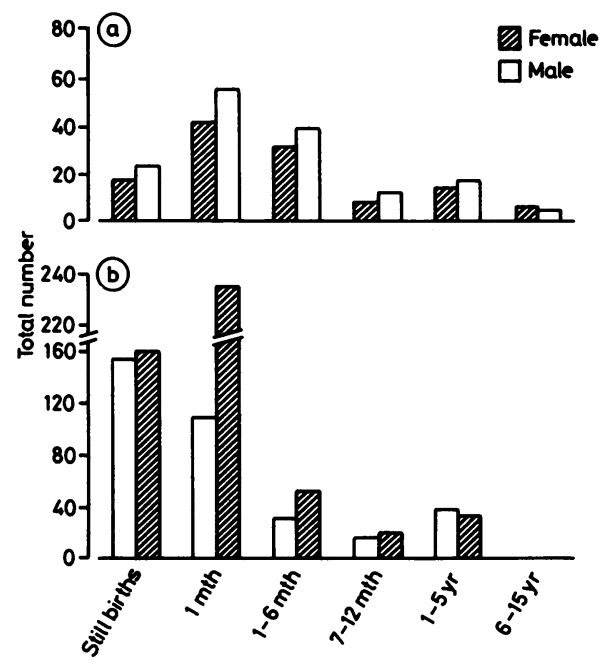

Fig 3 Age and sex distribution of children (a) with congenital heart disease (b) without congenital heart disease.

common in livebirths than stillbirths $(27.4 \%$ vs $11.6 \% \quad\left(\chi^{2} \quad\right.$ test $\left.\left.=34.49, \quad \mathrm{p}<0.0005\right)\right) . \quad$ The frequency of congenital heart malformation was $24.8 \%$ and $31.5 \%$ among liveborn boys and girls respectively, and $12 \cdot 8 \%$ and $10 \cdot 2 \%$ for stillbirths. The sex difference for livebirths is statistically significant $\left(\chi^{2}\right.$ test $\left.=4.28, p<0.05\right)$ but not for stillbirths $\left(\chi^{2}\right.$ test $\left.=0.59, p>0.4\right)$.

The forensic necropsies showed that 23 children $(17 \cdot 3 \%)$ had a congenital heart malformation. These

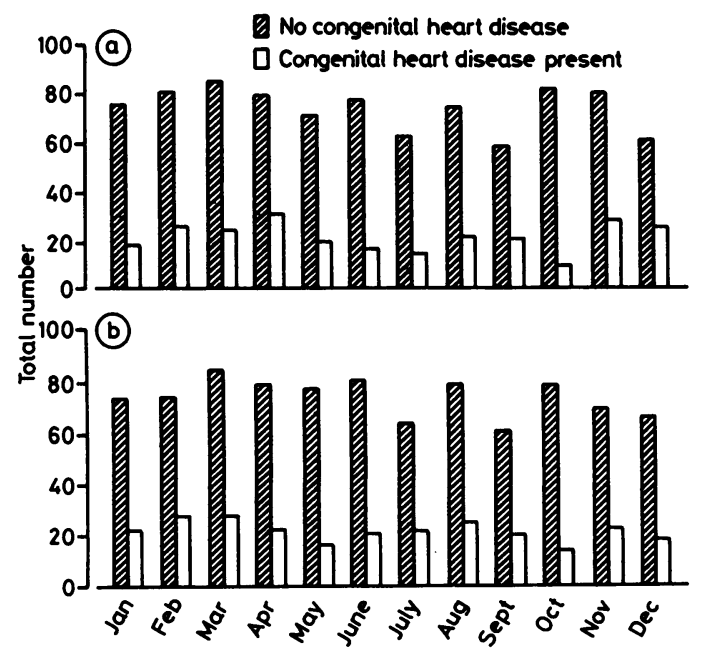

Fig 4 (a) Month of birth and (b) month of death of study group.

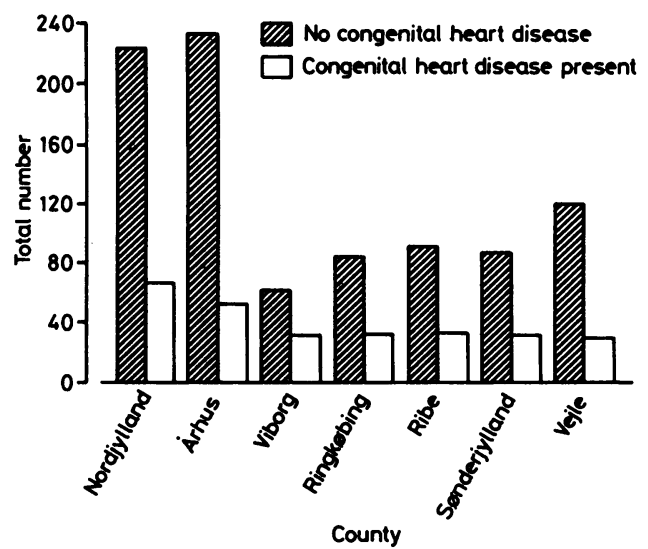

Fig 5 Distribution of all children in necropsy study according to county.

cases constituted $8.8 \%$ of all children with a congenital heart malformation.

Forty children had probe patency persisting beyond one month of age as the only malformation. Births of children with and without congenital heart malformation were equally distributed throughout the year $\left(\chi^{2}\right.$ test $=7 \cdot 34,11$ degrees of freedom, $\mathrm{p}>0 \cdot 7)$, as were deaths $\left(\chi^{2}\right.$ test $=11 \cdot 16,11$ degrees of freedom, $p>0 \cdot 1$ ) (fig $4 a$ and $b$ ).

Figure 5 shows the frequency of congenital heart malformation in different counties. There was no geographical variation in the rates of congenital heart malformation within Jutland $\left(\chi^{2}\right.$ test $=5 \cdot 71$, six degrees of freedom, $p>0 \cdot 4$ ).

Fifty three children had been operated upon because of congenital heart malformation. The majority $(79 \%)$ had died less than one month after the operation (table 2).

Two hundred and twenty seven (19.9\%) of all children had an extracardiac malformation (129 boys and 98 girls). The frequency of an extracardiac malformation was $19 \%$ among boys and $20.6 \%$ among girls $\left(\chi^{2}\right.$ test $=0.41, p>0.4$ ). Seventy nine (63 livebirths and 16 stillbirths) had a congenital heart malformation as well.

Extracardiac malformations were significantly

Table 2 Time from operation to death in 53 children operated on for congenital heart disease

\begin{tabular}{lc}
\hline Period & Died \\
\hline During operation & 8 \\
$<1$ week & 34 \\
$1-4$ weeks & 5 \\
$1-12$ months & 5 \\
$>1$ year & 1 \\
Total & 53 (25 girls/28 boys) \\
\hline
\end{tabular}




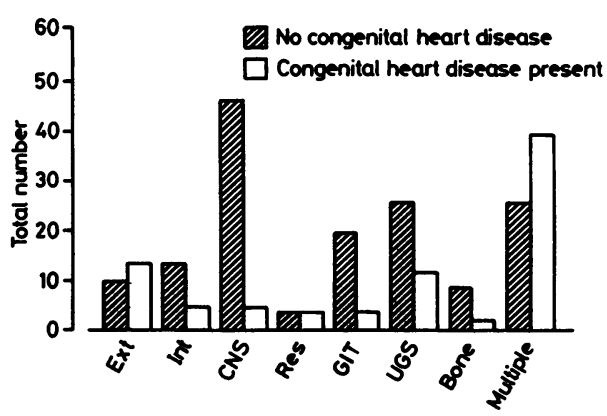

Fig 6 Extracardiac malformations in children with and without congenital heart disease. Ext, external (non-specified); Int, internal (non-specified); CNS, central nervous system; Res, respiratory system; GIT, gastrointestinal tract; UGS, urogenital system.

more frequent in those with congenital heart disease $(30.3 \%)$ than in those without $(16 \cdot 6 \%)$ (fig 6) $\left(\chi^{2}\right.$ test $\left.=24 \cdot 27, \mathrm{p}<0.0005\right)$. More than one other malformation was usually found in children with congenital heart disease. Twenty three children had

Table 3 Chromosomal abnormalities in study group

\begin{tabular}{llll}
\hline & & \multicolumn{2}{l}{$\begin{array}{l}\text { With congenital heart } \\
\text { malformation }\end{array}$} \\
\cline { 3 - 4 } $\begin{array}{l}\text { Abnormality } \\
\text { (syndrome) }\end{array}$ & $\begin{array}{c}\text { Total } \\
\text { number }\end{array}$ & Livebirths & Stillbirths \\
\hline Down's syndrome & $13 \mathrm{M}$ & 9 & 2 \\
Trisomy 18 & $10 \mathrm{~F}$ & 7 & 0 \\
Trisomy 18 mosaicism & $3 \mathrm{M}$ & 1 & 1 \\
Trisomy 13 & 6 F & 6 & 0 \\
& $2 \mathrm{M}$ & 0 & 0 \\
Interstitial deletion of & $2 \mathrm{~F}$ & 1 & 0 \\
short arm of & & 2 & 0 \\
chromosome 7 & $1 \mathrm{M}$ & & 0 \\
\hline
\end{tabular}

Table 4 Specific abnormalities in all children irrespective of chamber connections

\begin{tabular}{|c|c|c|c|c|}
\hline \multirow[b]{2}{*}{ Abnormality } & \multicolumn{2}{|c|}{ Livebirths } & \multicolumn{2}{|c|}{ Stillbirths } \\
\hline & $F$ & $M$ & $\boldsymbol{F}$ & $M$ \\
\hline $\begin{array}{l}\text { Abnormalities of pulmonary veins: } \\
\text { Supradiaphragmatic drainage } \\
\text { Infradiaphragmatic drainage }\end{array}$ & 1 & 7 & & 4 \\
\hline $\begin{array}{l}\text { Abnormalities of systemic veins: } \\
\text { Persistent superior vena cava } \\
\text { Others }\end{array}$ & $\begin{array}{l}6 \\
2\end{array}$ & $\begin{array}{l}2 \\
1\end{array}$ & & $\begin{array}{l}2 \\
1\end{array}$ \\
\hline $\begin{array}{l}\text { Cor triatriatum: } \\
\text { Left } \\
\text { Right }\end{array}$ & 1 & & & \\
\hline Atrial septal defect & 36 & 40 & 5 & 8 \\
\hline Probe patency ${ }^{\star}$ & 40 & 61 & 12 & 15 \\
\hline $\begin{array}{l}\text { Ventricular septal defect } \\
\text { Atrioventricular valve abnormalities: }\end{array}$ & 48 & 43 & 10 & 14 \\
\hline Mitral & 9 & 9 & & 1 \\
\hline Tricuspid & 1 & 6 & & \\
\hline Both & 1 & 1 & & \\
\hline $\begin{array}{l}\text { Atrioventricular septal defects } \\
\text { Hypoplasia of ventricles: }\end{array}$ & 6 & 9 & & 2 \\
\hline $\begin{array}{l}\text { Left } \\
\text { Right }\end{array}$ & 4 & 11 & $\begin{array}{l}1 \\
1\end{array}$ & \\
\hline $\begin{array}{l}\text { Ventricular outlet tract: } \\
\text { Subvalvar aorta/pulmonary } \\
\text { artery }\end{array}$ & $0 / 4$ & $1 / 5$ & & $0 / 1$ \\
\hline $\begin{array}{l}\text { Valvar aorta/pulmonary artery } \\
\text { Supravalvar aorta/pulmonary }\end{array}$ & $14 / 18$ & $23 / 18$ & $2 / 3$ & $1 / 3$ \\
\hline $\begin{array}{l}\text { artery } \dagger \\
\text { Fallot's tetralogy } \ddagger \\
\text { Abnormalities of aortic arch: }\end{array}$ & $\begin{array}{l}4 / 5 \\
5\end{array}$ & $\begin{array}{l}3 / 6 \\
10\end{array}$ & $\begin{array}{l}1 / 1 \\
1\end{array}$ & \\
\hline $\begin{array}{l}\text { Coarctation } \\
\text { Other }\end{array}$ & $\begin{array}{r}13 \\
8\end{array}$ & $\begin{array}{r}12 \\
9\end{array}$ & $\begin{array}{l}1 \\
2\end{array}$ & $\begin{array}{l}2 \\
2\end{array}$ \\
\hline $\begin{array}{l}\text { Abnormalities of systemic } \\
\text { arteries } \\
\text { Abnormalities of pulmonary }\end{array}$ & 2 & 6 & & 1 \\
\hline $\begin{array}{l}\text { trunk and arteries } \\
\text { Patent ductus arteriosus }\end{array}$ & $\begin{array}{r}6 \\
51\end{array}$ & $\begin{array}{r}9 \\
71\end{array}$ & $\begin{array}{r}1 \\
16\end{array}$ & $\begin{array}{r}2 \\
20\end{array}$ \\
\hline
\end{tabular}

*Probe patency or persistent ductus arteriosus or both in stillbirths were recorded only in combination with other heart malformations.

tThese cases include membranes and hypoplastic arteries. In Scandinavia and Germany this abnormality is known as Steno-Fallot's: Niels Stensen (1638-86), Danish anatomist, geologist, and theologian.

Table 5 Data on cases of double inlet ventricles and absence of atrioventricular connection

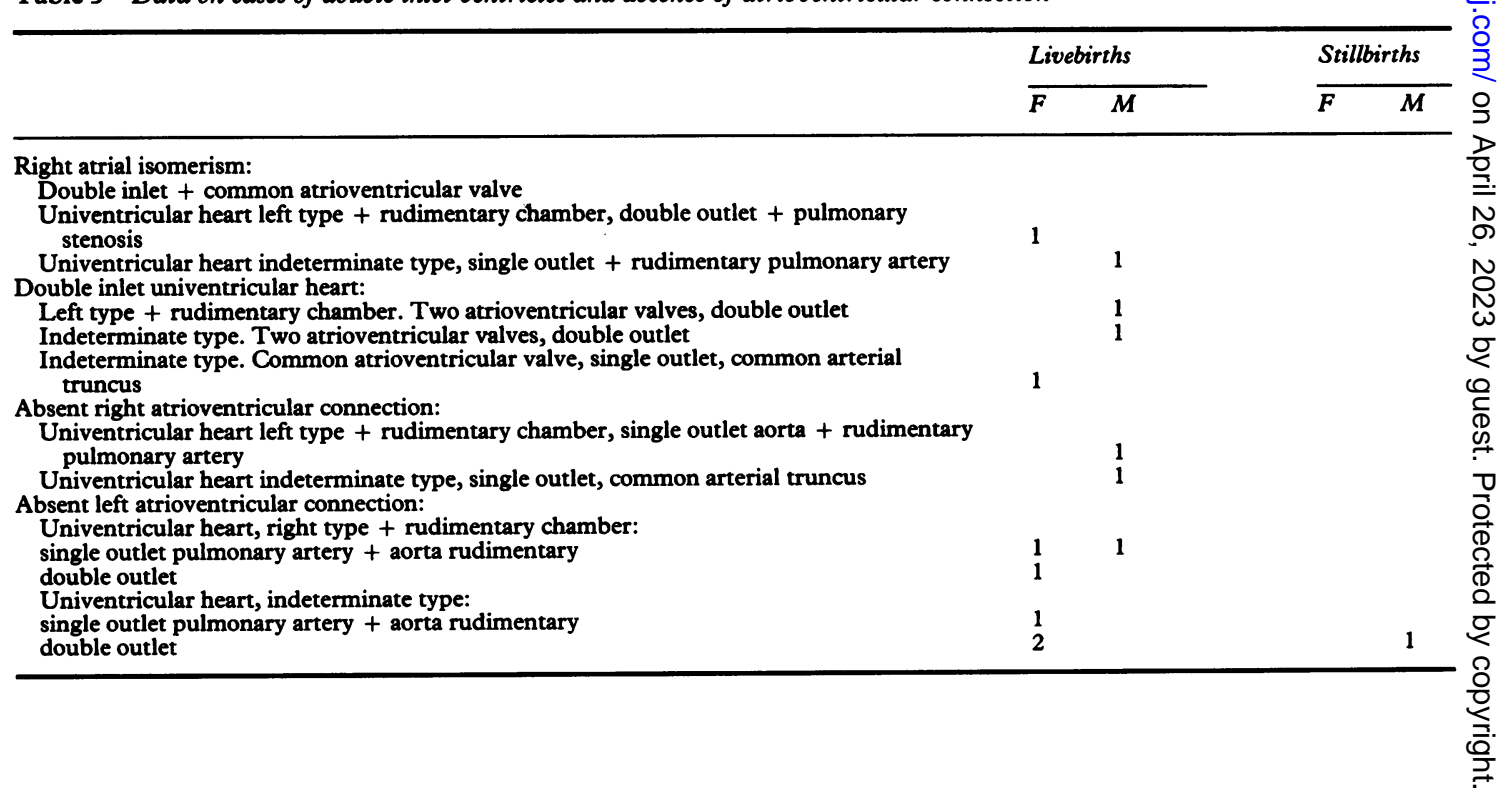


Table 6 Cases of abnormal connections of chamber to chamber and to great arteries in study group

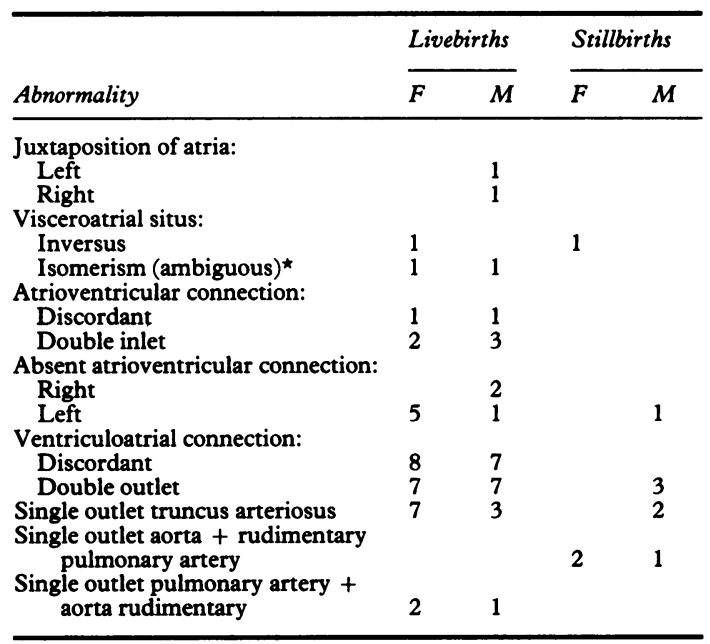

$\star^{\star}$ Two cases of right isomerism with asplenia.

Down's syndrome and of these $18(78 \%)$ had congenital heart malformation. Syndromes other than Down's were found in 15 children $(1.3 \%$ of the entire study group), and 12 children ( $80 \%$ ) had congenital heart malformations.

The congenital heart malformation was estimated to be the cause of death or the major contributing factor of death in $181(82 \%)$ of 221 livebirths.

\section{CLASSIFICATION ACCORDING TO SEQUENTIAL} SEGMENTAL ANALYSIS

In the tables we have concentrated on giving the numbers of specific anomalies with normal and abnormal chamber connections and with abnormalities of the great arteries (tables 4-6). Thus

Table 7 Other congenital heart abnormalities

\begin{tabular}{|c|c|c|c|c|c|}
\hline \multirow[b]{2}{*}{ Abnormality (of) } & \multicolumn{2}{|c|}{ Livebirths } & \multicolumn{2}{|c|}{ Stillbirths } & \multirow{2}{*}{$\begin{array}{l}\text { Combined with } \\
\text { other heart } \\
\text { "abnormalities" }\end{array}$} \\
\hline & $F$ & $M$ & $F$ & $M$ & \\
\hline \multirow{7}{*}{$\begin{array}{l}\text { Coronary artery } \\
\text { Coronary sinus } \dagger \\
\text { Endocardium } \\
\text { (fibroelastosis) } \ddagger \\
\text { Pericardium } \\
\text { (defects) } \\
\text { Ebstein's } \\
\text { Aneurysm of patent } \\
\text { ductus arteriosus } \\
\text { Congenital } \\
\text { atrioventricular } \\
\text { block }\end{array}$} & 5 & 2 & \multirow{7}{*}{2} & \multirow{4}{*}{1} & 5 \\
\hline & 1 & 3 & & & 5 \\
\hline & 2 & 9 & & & 11 \\
\hline & & & & & 3 \\
\hline & & 1 & & & 1 \\
\hline & & 1 & & & 1 \\
\hline & 1 & & & & 1 \\
\hline
\end{tabular}

^Common origin (one ostium) 3; both ostia in one sinus 2; left coronary artery from pulmonary artery 1 ; missing circumflex artery 1.

+ Stenosis 1 ; atresia 4.

$\ddagger$ Hypoplastic left ventricle syndrome not included. an individual patient often appears several times. Furthermore, we have counted and listed separately abnormalities of the coronary arteries (origin or number), anomalies of the coronary sinus, pericardial malformations, and congenital fibroelastosis of the newborn (table 7).

\section{Discussion}

The death rate in the study population was $1.5 \%$, and 521 stillbirths were registered during the study period. Necropsies were performed in $68.8 \%$ and of these $89.2 \%$ were investigated by us. There are at least two explanations why we were unable to assess all cases: (a) not all cases were referred to us by the primary departments (failure of communication) and $(b)$ the official records of the National Health Board are not exhaustive.

Most studies of congenital heart malformation have been restricted to a category of congenital heart malformation or they have been population studies of both live and dead children. Some investigators have examined the frequency of various disorders by analysing museum collections of congenitally malformed hearts thus expressing the frequency of a malformation by relating it to other abnormalities. Our results cannot be compared with such studies.

Our study was conducted at the end point of the disease process. The congenital heart malformation was regarded as the cause of death or the major contributing factor of death in $181(82 \%)$ of 221 liveborn cases. In a detailed study Sămánek et al found that congenital heart malformations were a major contributing factor in about $50 \%$ of deaths. ${ }^{3}$

About $0 \cdot 6-0 \cdot 8 \%$ of neonates have a congenital heart malformation. ${ }^{3}$ The dead children aged $0-14$ years that we studied are equivalent to $0.27 \%$ of the total number of infants born in the study period. Among the children aged 0-14 years who died congenital heart malformation was common $(22.6 \%$ of investigated cases) and was the cause of death in $18 \%$ of children.

We have found one necropsy study which we think may be compared with our investigation. ${ }^{4}$ Because the grouping of patients is different only parts of the two studies can be compared. In a study of stillbirths and livebirths aged up to one year Wilson and Lubschez found congenital heart malformation in $6 \%{ }^{4}$ whereas we found $22.6 \%$ in our study. The reasons for this discrepancy are not apparent. Gibson reported a frequency of $12 \%$ of congenital heart malformation in 1633 necropsies from the Great Ormond Street Clinic, ${ }^{5}$ and Nestor and Rice $20 \%$ among 675 necropsies. ${ }^{6}$ In Gibson's study the age of cases is not given and Nestor and Rice's study did not include stillbirths. The age 
range in Nestor and Rice's study is, however, identical with ours (0-14 years) and the results are in the same range $(20 \%$ vs $27 \%$ in our study after the exclusion of stillbirths from our study). Recent studies of cardiac malformations in spontaneous abortions by Gerlis ${ }^{7}$ and Ursell et $a l^{8}$ cannot be compared with our study as they deal with aborted fetuses of $<24$ or 28 weeks' gestation (which for all practical purposes are fetuses with a birth weight below $1000 \mathrm{~g}$ ).

Although our study is quite large some of the groups of anomalies are too small for valid statistical analysis; however, some trends are apparent in the new data. The tables that we constructed to show which malformation appeared with other abnormalities have been omitted because they are too complicated to read.

Some solitary anomalies occurred but combinations of malformations were more common. There were only 24 cases of isolated ventricular septal defects (livebirths: five boys, and seven girls; stillbirths: nine boys and three girls), 19 patients with isolated atrial septal defects (livebirths: eight boys and four girls; stillbirths: three boys and four girls), and 14 with persistent ductus arteriosus (five boys and nine girls; stillbirths were not included).

The aim of the study has been to demonstrate the use of the sequential segmental analysis as a routine method of describing congenital heart abnormalities. We found that sequential segmental analysis is a logical and convenient approach and one which because of its stepwise structure ensures a thorough investigation. Although there was considerable discussion about some cases, none of them was unclassifiable by this analysis. We believe that sequential chamber analysis is the method of choice for describing congenital heart malformations.

We thank all our colleagues who have supplied the material and The Medical Research Foundations of Nordjylland and Ålborg for financial support.

\section{References}

1 Shinebourne EA, Macartney FJ, Anderson RH. Sequential chamber localization-logical approach to diagnosis in congenital heart disease. Br Heart $J$ 1976;38:327-40.

2 Becker AE, Anderson RH. Pathology of congenital heart disease. (In: Crawford $\mathrm{T}$, ed. Postgraduate pathology series.) London, Boston, Sydney, Wellington, Durban, Toronto: Butterworths, 1981.

3 Sămánek M, Goetzová J, Benešová D. Causes of death in neonates born with a heart malformation. Int $J$ Cardiol 1986;11:63-74.

4 Wilson MG, Lubschez R. Prognosis for children with congenital anomalies of the heart and central vessels. Life expectancy in patent ductus arteriosus. $J$ Pediatr 1942;21:23-30.

5 Gibson WM. A survey of the post-mortem findings in 200 cases of congenital heart disease. Gr Ormond Str $J$ 1956;11:69-75.

6 Nestor JO, Rice EC. Heart disease in children. Med Ann Distr Columbia 1956;25:616-7.

7 Gerlis LM. Cardiac malformations in spontaneous abortions. Int J Cardiol 1985;7:29-43.

8 Ursell PC, Byrne JM, Strobino BA. Significance of cardiac defect in the developing fetus: a study of spontaneous abortuses. Circulation 1985;72:1232-6. 